\title{
Era Kekinian Publikasi Open Journal Systems dan Perancangan Identitas Visual Jurnal Bali Membangun Bali
}

\author{
I Nyoman Anom Fajaraditya Setiawan \\ STMIK STIKOM Indonesia \\ Email: anomkojar@stiki-indonesia.ac.id
}

\begin{abstract}
ABSTRAK
Kebutuhan publikasi pada era kekinian sebagai wadah diseminasi informasi dan pengetahuan terutama tentang pembangunan menjadi hal yang penting. Jurnal Bali Membangun Bali sebagai salah satu wadah publikasi merupakan tindakan yang cerdas dalam mensiasati proses pembangunan dan kemajuan pembangunan secara berkesinambungan. Sarana publikasi online menjadi sarana yang tepat dalam publikasi hasil-hasil kajian dan seiring pula dengan himbauan Permenristek melalui Dirjen Dikti prihal publikasi. Adanya sarana online, selain dikelola tim profesional pada bidangnya, diperlukan pula suatu identitas yang mencirikan dan pengantar pesan dari JBMB. Penciptaan identitas visual berupa logo dilakukan dengan beragam pertimbangan dan analisis riset sehingga identitas tersebut dapat berfungsi sebagai mana mestinya. Logo pada BMB menjadi berperan karena mengakomodir filosofis dari rancangan JBMB diterbitkan. Penciptaan menggunakan metode deskriptif dan runut sehingga proses dapat diikuti dalam pembahasan. Sebagai logo perwakilan entitas BMB akan menjadi bagian popularitas diseminasi riset dan pembangunan yang ada di Provinsi Bali.
\end{abstract}

Kata Kunci: publikasi, OJS, identitas, visual, Jurnal Bali Membangun Bali

\begin{abstract}
The need for publications in the current era as a means of disseminating information and knowledge, especially about development, becomes essential. Bali Menbangun Bali, as one of the publications, is an intelligent act in anticipating the development process and development progress in a sustainable manner. The online publication tool is the right tool in the publication of the results of the study and is also in line with the appeal of the Minister of Research and Technology through the Director-General of Higher Education regarding publication. The existence of online facilities, in addition to being managed by a professional team in their fields, also requires an identity that characterizes and introduces messages from $B M B$. The creation of a visual identity in the form of a logo is carried out with a variety of considerations and research analysis so that the identity can function as it should. The logo on BMB becomes a role because it accommodates the philosophical design of the BMB published. Creation uses descriptive and traces methods so that the process can be followed in the discussion. As a representative logo of the BMB entity will be part of the popularity of research and development dissemination in the Province of Bali.
\end{abstract}

Keywords: publications, OJS, identity, visuals, Bali Membangun Bali Journal. 


\section{PENDAHULUAN}

Media publikasi merupakan wadah dalam penyebaran informasi dan pengetahuan ke khalayak luas. Media publikasi biasanya dimanfaatkan dalam berbagai tujuan guna mempublikasikan hasil-hasil kajian, temuan, analisis dan beragam hasil penelitian atau sejenisnya. Publikasi ilmiah biasanya dimanfaatkan oleh para profesional ataupun akademisi dengan tujuan mempublikasikan tulisan mereka. Namun tidak menutup kemungkinan bahwa kalangan umum juga dapat mempublikasikan tulisan mereka sebagai praktisi ataupun hasil riset yang telah mereka lakukan. Pada kehidupan akademis biasanya publikasi ilmiah dimanfaatkan sebagai sarana pengumpulan angka kredit untuk memenuhi pelaksanaan kewajiban tri dharma.

Media publikasi ilmiah memiliki beberapa jenis istilah, salah satu diantaranya dalam bentuk jurnal ilmiah. Jurnal ilmiah merupakan media diseminasi hasil penelitian yang biasanya memiliki terbitan berkala dengan beberapa terbitan setiap tahun. Artikel pada jurnal ilmiah secara teoritis tentunya memiliki sifat ilmiah dalam artian melalui proses riset dengan penerapan metode. Artikel pada suatu jurnal dikategorikan dalam bentuk disiplin atau subdisiplin tertentu, namun terdapat pula suatu jurnal yang dikategorikan berdasarkan tema tiap terbitan secara aktual. Hal yang menarik pada jurnal ilmiah adalah dikemukakannya berbagai ilmu dengan temuan serta fakta-fakta terkini yang teranalisis dengan susunan runut dalam bahasannya. Secara umum pula, para penulis mencari sumber refenrensi pada berbagai jurnal ilmiah dengan limit waktu tertentu untuk mengedepankan kebaruan temuan.

Salah satu publikasi dalam bentuk jurnal adalah terbitan Jurnal Bali Membangun Bali untuk mengakomodir topik tentang Bali. Topik yang diangkat merupakan hasil-hasil kajian seputar pembangunan Bali yang merupakan mendiseminasi hasil riset, pengkajian, pengembangan, penerapan, invensi, dan inovasi pembangunan daerah terkait upaya peningkatan dan kemajuan pembangunan, peradaban, dan kesejahteraan masyarakat Provinsi Bali. Sebagaimana ditunjukkan melalui visi dan misinya, JBMB hadir sebagai sebuah media ilmiah dalam rangka pengembangan diskursus dan penyemaian informasi pembangunan di beragam ranah yang mencakup penelitian dan pengembangan (research and development), perencanaan infrastruktur dan pengembangan wilayah, ekonomi, sosial, budaya, ketataprajaan serta pengendalian dan evaluasi (Putra, 2018).

Bali Membangun Bali (BMB) sebagai wadah kajian sebelumnya bernaung di bawah institusi pemerintah Badan Perencanaan Pembangunan Daerah Penelitian dan Pengembangan (BAPPEDA LITBANG) Provinsi Bali sekaligus sebagai lembaga penerbitan jurnal tersebut. Tujuan awalnya pun untuk mengakomodir beragam kajian 
seperti halnya dari tim-tim ahli, pejabat kedinasan, praktisi atau profesional dan akademisi terkait pembangunan di Bali. BMB sekaligus pula sebagai media pengembangan diskursus dan penyebaran informasi pengembangan daerah, khususnya di beragam ranah; penelitian dan pengembangan; perencananaan; pengendalian dan evaluasi; infrastruktur dan pengembangan wilayah; ekonomi, sosial, budaya, teknologi, dan ketataprajaan. Diterbitkan secara berkala catur wulan atau tiga terbitan dalam setahun yakni April, Agustus, dan Desember sejak 2018. Dapat dikatakan pula BMB merupakan salah satu wadah pelopor dari instansi pemerintahan di Bali yang menerbitkan jurnal tentang seputar pembangunan daerah ke khalayak publik.

Pada tahun 2020 awal, BMB berbenah menuju ke kelembagaan dan penerbitan yang baru yaitu Badan Riset dan Inovasi Daerah Provinsi Bali. Pada perubahan ini, sistem pada jurnal pun ikut berbenah menuju sistem yang lebih modern mengikuti perkembangan teknologi khususnya pada penerbitan jurnal. Perubahan sistem yang dimaksud adalah pembangunan dengan Open Journal Systems (OJS), sehingga suatu terbitan ilmiah dapat dibuka seluas-luasnya melalui media online (internet). Hal ini seiring pula dengan Perdirjen nomor 49/DIKTI/Kep/2011 tentang Pedoman Akreditasi Berkala IImiah yang dikatakan untuk meningkatkan daya saing dalam berkiprah, memperluas aspirasi dan wawasannya, meningkatkan mutu produk kecendekiaan, sehingga akan dapat pula meningkatkan produk ekonomi ke taraf internasional serta produksi tulisan yang didasari oleh penelitian empirik dan telaahan yang ditujukan untuk menghasilkan peningkatan temuan dan pendapat orisinil dan baru (novelties, new to science) (D. DIKTI, 2011).

Adanya peningkatan kearah OJS, maka BMB pun harus berbenah dan mempersiapkan beragam infrastruktur yang dibutuhkan. Perlu dicatatat bahwa penerbitan $\mathrm{BMB}$ hanya terbatas pada penerbitan hard print dengan nomor International Standard Serial Number (ISSN) yang jangkauan dan cetaknya sangatlah terbatas. Kembali pada bahasan infrastruktur selain untuk persiapan ruang digital, juga memerlukan suatu identitas visual untuk mendukung popularitas publikasi. Hal ini merupakan gagasan dari tim penyunting ahli yang merupakan salah satu agenda khusus pembangunan OJS BMB secara berkelanjutan. Logo pada hakekatnya pula sebagai identitas visual yang berdampak pada branding BMB, setidaknya membangun suatu fondasi BMB sebagai salah satu jurnal ilmiah populer yang dikelola dengan profesional pada institusi pemerintah. Adanya identitas visual dapat pula memberikan dampak pada ciri khas BMB sebagai media publikasi dari Bali. Jika dirumuskan, terdapat dua hal mendasar pada ulasan ini yakni pemahaman tentang OJS dan penciptaan identitas visual sebagai sarana peningkatan popularitas jurnal. Pada 
akhirnya, untuk menjawab kedua hal tersebut, maka solusi yang didapatkan akan berdampak pada penyadaran pentingnya publikasi dan branding secara umum.
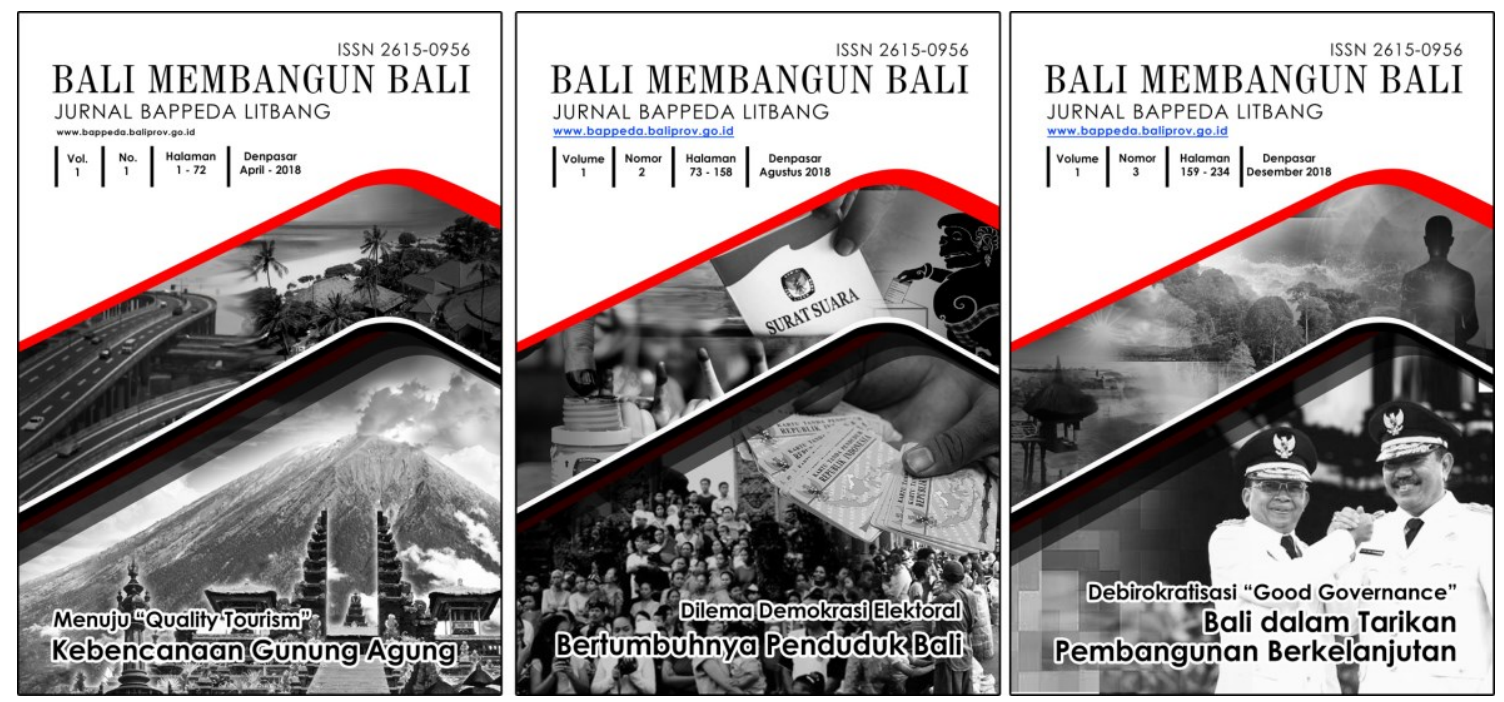

Gambar 1. Terbitan Bali Membangun Bali oleh pengelola sebelumnya (2018)

\section{NUANSA KEBARUAN DALAM TERBITAN BARU}

Sejak adanya perubahan pengelolaan dan seiring dengan pengembangan yang mengarah pada sistem berjaringan, maka muncul gagasan untuk merubah secara totalitas tatanan visual jurnal ini. Rancangan pada sampul kemudian dirombak sekaligus namun tanpa meninggalkan nuansa popularitas jurnal Bali Membangun Bali. Tatanan elemen visual pada rancangan sampul dirubah menjadi lebih menarik dengan sandingan warna, ilustrasi, dan susunan teks pada sampul. Nuansa tersebut mengambil intisari dari konsep Nangun Sat Kerthi Loka Bali dan elemen-elemen yang saling berkaitan. Hal ini tentu akan menjadi dasar pemikiran terutama brand yang telah terbangun dari komponen jurnal, konsep, tujuan dan sebagainya yang terakomodir dalam Jurnal Bali Membangun Bali (JBMB) dengan nama dan wadah baru.

Adanya struktur perubahan rancangan pada sampul dan berkaitan dengan etika penerbitan jurnal (tentang susunan elemen visual ilustrasi, teks, dan warna yang tidak boleh berubah), demi mengedepankan kebaruan maka dilakukanlah pengajuan ISSN yang baru baik itu secara elektronik dan cetak. Totalitas ini pun menjadi momentum memperkuat nuansa jurnal dengan penciptaan logo sebagai profesionalisme eksistensi suatu tindakan dalam wadah publikasi. Dengan demikian, logo pun secepatnya dieksekusi beiringan dengan perancangan baru sampul jurnal dengan nuansa kebaruan. Sehingga pembahasan berikutnya, proses penciptaan logo dan visualisasi akhir dari sampul dapat menunjukkan semangat baru dalam visi membangun Bali pada Badan Riset Inovasi Daerah Provinsi Bali. 


\section{KAJIAN SUMBER}

\section{Media Publikasi dan Open Journal Systems}

Sebelum merujuk pada topik inti, dirasa perlu dijelaskan tentang jenis dari media publikasi sebagai media penyebarluasan informasi dan pengetahuan sebagai pengantar. Media publikasi dalam hal ini yang berbentuk ilmiah terdapat beberapa jenis yang beberapa diantaranya yakni: (1) presentasi pada forum ilmiah yaitu dari hasil paparan narasumber pada seminar atau loka karya ilmiah; (2) laporan hasil penelitian yaitu terbitan berdasarkan acuan tindakan riset ataupun pengujian misal dalam bentuk buku yang ber-ISBN ataupun terbit sebagai artikel ilmiah; (3) makalah atau tinjauan ilmiah yaitu tinjauan dalam bentuk karya tulis ilmiah yang berupa gagasan dalam upaya penemuan solusi; (4) tulisan ilmiah populer yaitu tulisan ilmiah yang dipublikasikan di media massa; (5) buku ajar yaitu penyusunan buku yang berisi pengetahuan bidang ilmu atau pelajaran tertentu yang diperuntukkan pada siswa atau mahasiswa; (6) modul dan diktat yaitu modul merupakan susunan materi yang disajikan secara tertulis sehingga pembaca dapat menyerap sendiri materi tersebut, sedangkan diktat merupakan catatan-catatan tertulis untuk memeperkaya materi studi dalam proses belajar mengajar; (7) karya terjemahan yaitu tulisan yang dihasilkan dari alih bahasa pada materi buku yang berbahasa selain dari bahasa indonesia; (8) artikel ilmiah yaitu susunan tulisan yang berisi gagasan yang biasanya diterbitkan pada media jurnal ilmiah (Guru, 2013). Beberapa yang disebutkan pada kutipan, beberapa diantaranya susunan tulisan yang dihasilkan dari suatu telaah ilmu atau fenomena cenderung dipublikasikan pada jurnal ilmiah yang mengedepankan kebaruan.

Secara konsep, terbitan jurnal dapat dibagi menjadi dua jenis yaitu terbitan secara cetak dan elektronik. Jurnal cetak atau tercetak merupakan terbitan berkala yang diproduksi dengan proses publikasi cetak konvensional atau yang biasa disebut dengan hard print, hard copy, atau p-jurnal dengan ditandakan nomor seri $\mathrm{p}$-ISSN. Sedangkan jurnal elektronik memiliki prinsip yang hampir sama, namun cenderung dipublikasikan dalam bentuk elektronik yang ditandakan dengan nomor serial e-ISSN. Tetapi pada era kekinian, publikasi jurnal ilmiah justru dipermudah dengan memanfaatkan jaringan internet sebagai sarana penyebarluasan jurnal. Kini telah ada suatu sistem yang sangat membantu proses penerbitan khususnya publikasi jurnal yang bernama OJS. Sistem ini dimanfaatkan untuk pengaturan dan penerbitan jurnal berbasis web disebut sebagai Open Journal Systems (atau biasa disebut OJS) serta meliputi semua aspek penerbitan secara online. OJS memiliki tujuan mempermudah beragam tugas operasional, dari submisi artikel, koreksi, peninjauan, publikasi, 
indeksasi dan sebagainya. OJS memiliki sistem yang fleksibel dan dapat diukur (Nurudin, 2013). Adapun kelebihan dan kekurangannya dapat dilihat pada tabel 1.

Tabel 1. Kelebihan dan kekurangan publikasi jurnal antara e-jurnal dan p-jurnal [Sumber: Nurudin, 2013]

\begin{tabular}{|c|c|c|c|}
\hline No. & Kriteria & Jurnal Elektronik & Jurnal Cetak/Print \\
\hline 1 & Kemutakhiran & Mutakhir & Mutakhir \\
\hline 2 & Kecepatan diterima & Cepat & Lambat \\
\hline 3 & Penyimpanan & Sangat mengirit tempat & Memakan tempat \\
\hline 4 & Pemanfaatan & 24 jam & Terbatas jam buka \\
\hline 5 & Kesempatan & akses Bisa bersamaan & Antri \\
\hline 6 & Penelusuran & Otomatis tersedia & Harus dibuat \\
\hline 7 & Waktu penelusuran & Cepat & Lama \\
\hline 8 & Keamanan & Lebih aman & Kurang aman \\
\hline 9 & Manipulasi dokumen & Sangat mudah & $\begin{array}{l}\text { Tidak bisa (sepert } \\
\text { kutipan, dsb) }\end{array}$ \\
\hline 10 & $\begin{array}{l}\text { Bila langganan dengan } \\
\text { dana yang sama (jurnal } \\
\text { lokal) }\end{array}$ & Judul bisa lebih banyak & Judul lebih sedikit \\
\hline 11 & Harga total langganan & Jauh lebih murah & Lebih mahal \\
\hline
\end{tabular}

Masih berkaitan dengan publikasi dalam e-jurnal, terdapat dua jenis arah publikasi berdasarkan luas wilayah yaitu jurnal nasional dan jurnal internasional. Terkait indeksasi, jurnal yang ada selayaknya memiliki dampak yaitu bahwa artikel ilmiah yang dipublikasikan dalam jurnal dapat dikembangkan dengan acuan sitasi pada artikel dari jurnal yang berbeda. Tingkatan sitasi dengan memanfaatkan aplikasi sitasi akan terlihat pada indeksasi publikasi ilmiah salah satunya yang sangat umum adalah media google scholar. Hal ini dapat dijadikan asumsi keaktifan dari penulis dalam melakukan publikasi serta dimanfaatkan sebagai acuan pengembangan ilmu oleh penulis lain. Selain itu, hal ini juga akan berdampak luas jika keaktifan tersebut diikuti banyak penulis, karena dapat menaikkan referensi indeks publikasi dan bahkan daya saing suatu negara terhadap negara lain dari sisi tertentu.

Kaitan publikasi suatu negara, tanpa disadari bermula dari hal terkecil misal salah satunya dengan acuan publikasi ilmiah untuk memprediksikan tingkat pengembangan ilmu ataupun pendidikan dari kualitas dan kuantitas terbitan suatu negara. Sedangkan di Indonesia sarana yang dapat secara pasti dijadikan acuan untuk penulis adalah Sinta. Seperti yang diungkapkan pada web Sinta yakni; Sinta (Indeks 
Sains dan Teknologi), memberikan akses untuk kutipan dan keahlian di Indonesia. Sistem informasi penelitian berbasis web menawarkan akses cepat, mudah dan komprehensif untuk mengukur kinerja para peneliti, lembaga dan jurnal di Indonesia. Sinta memberikan tolok ukur dan analisis, identifikasi kekuatan penelitian masingmasing lembaga untuk mengembangkan kemitraan kolaboratif, untuk menganalisis tren penelitian dan direktori ahli. Sinta diinisiasi pada tahun 2016 oleh Direktur Jenderal Penguatan Penelitian dan Pengembangan, Kementerian Teknologi Riset dan Pendidikan Tinggi Republik Indonesia, dengan melibatkan para ahli dari berbagai institusi. Konten Sinta dari jurnal Indonesia yang telah diterbitkan secara elektronik memiliki profil atau google scholar dan preview Scopus berisi sejumlah kutipan, indeks$\mathrm{h}$, indeks $\mathrm{i}-10$, pengembangan selanjutnya akan mencakup makalah proses, buku dan paten peneliti di Indonesia, dan profil penulis dari google scholar (K. DIKTI, 2016).
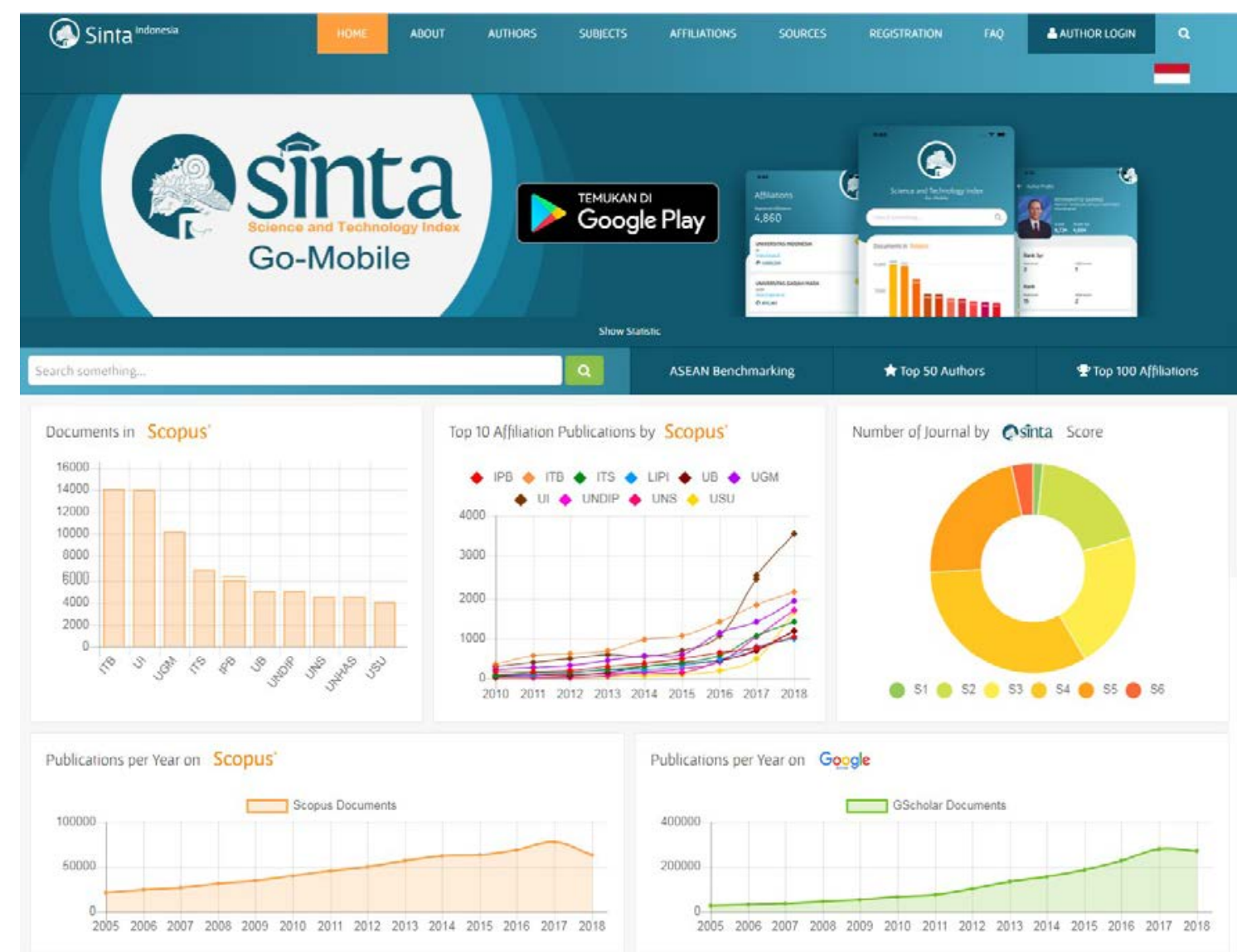

Gambar 2. Halaman utama Sinta (scroll atas) tentang menu, grafik, afiliasi, dan sebagainya [Sumber: http://sinta2.ristekdikti.go.id/] 


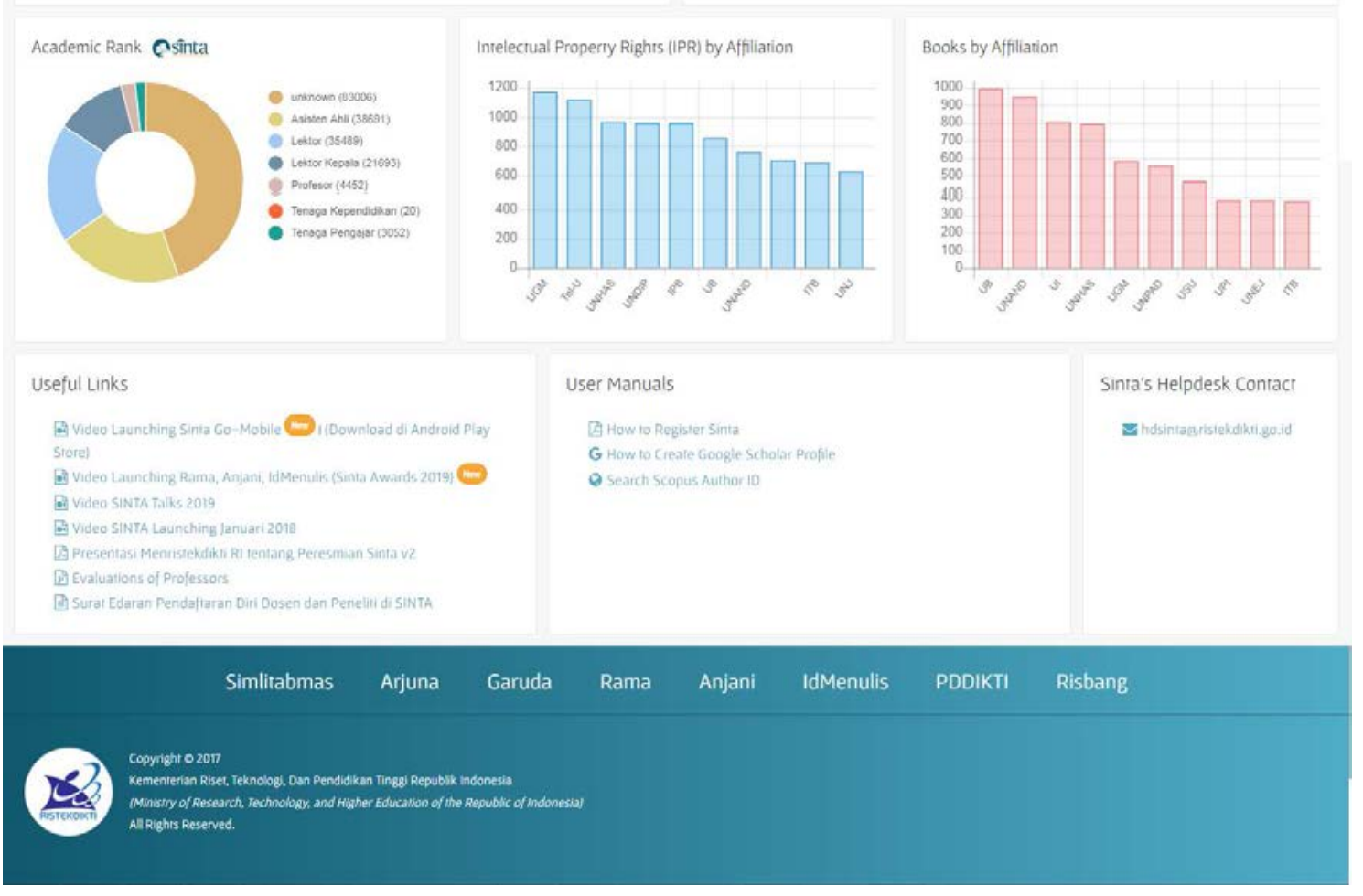

Gambar 3. Halaman utama Sinta (scroll bawah) yang menampilkan tutor, link terkait, dan sebagainya

[Sumber: http://sinta2.ristekdikti.go.id/]

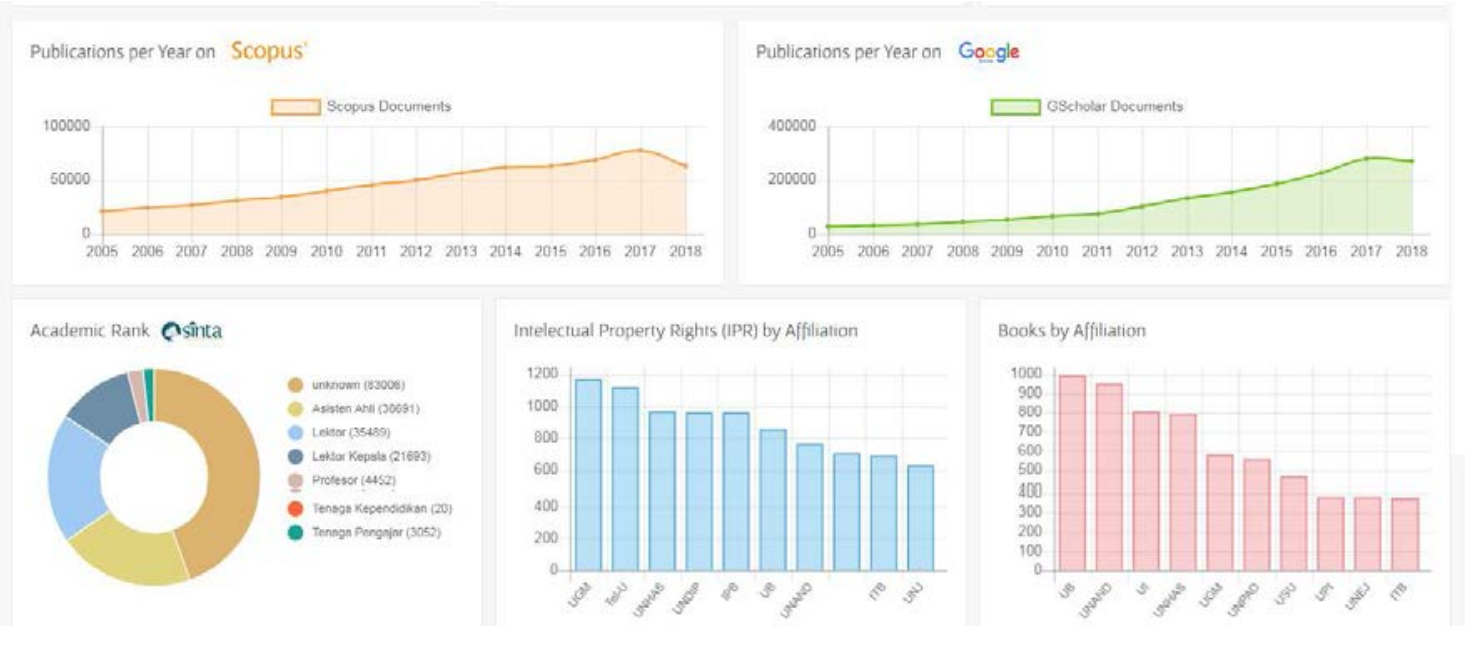

Gambar 4. Halaman utama Sinta (scroll tengah) menampilkan grafik pulikasi dan indeksasi [Sumber: http://sinta2.ristekdikti.go.id/] 


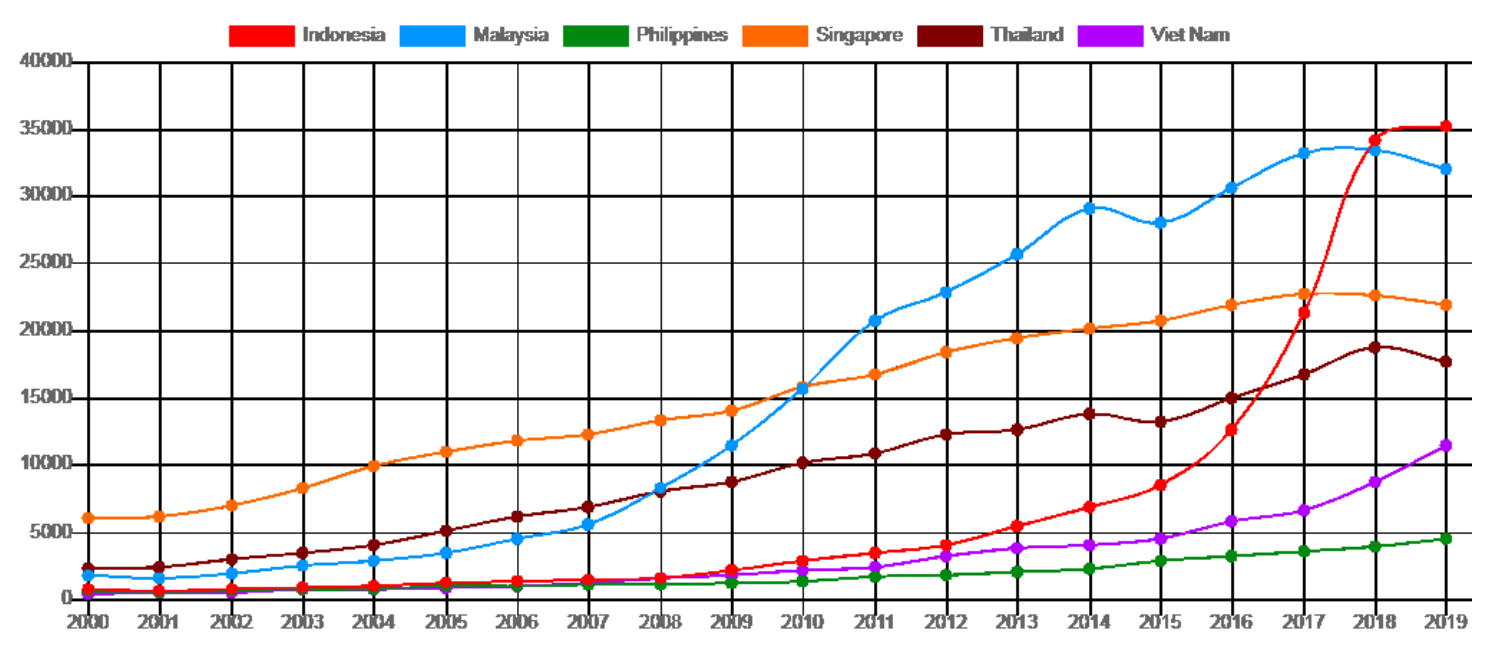

Gambar 5. Indeks publikasi wilayah ASEAN dan Indonesia pada peringkat teratas dengan 35.132 publikasi di tahun 2019

[Sumber: http://sinta2.ristekdikti.go.id/]

\section{Identitas Visual dalam Kerangka Teoritik}

Agenda berikutnya dalam ulasan artikel ini dalah tentang perancangan identitas visual Jurnal Bali Membangun Bali. Sebelum dibahas secara komprehensif dalam bab pembahasan, dirasa perlu untuk memahami identitas visual dari sudut pandang dan pemahaman referensi teoritis. Identitas visual memiliki banyak ragam dan jenis, secara harfiah merupakan perwakilan dari instansi atau institusi, perusahaan, komunitas, kelompok dan sebagainya. Identitas visual memanfaatkan elemen grafis seperti halnya garis, bidang, warna, yang dianggap mampu mempresentasikan citra ataupun karakteristik entitasnya (Setiawan dan Jayanegara, 2019). Pembahasan identitas terkait dengan $\mathrm{BMB}$, adalah penciptaan logo dari $\mathrm{BMB}$ dan disamping itu dapat dikatakan pula logo sebagai salah satu yang memproduksi tanda menjadi bagian penting dari BMB.

Suatu logo diperoleh maknanya dari suatu kualitas yang disimbolkan berdasarkan faktor internal maupun faktor eksternal yang mempengaruhi logo itu sendiri. Adapun pengaruh dari faktor internal dapat berupa bentuk dan warna sedangkan pada pengaruh faktor eksternal dapat berupa visi, misi, jenis usaha, dan citra. Faktor-faktor tersebut yang menjadikan logo mampu memberikan nilai lebih, kekhasan, maupun keunikan yang pada akhirnya mampu membuat sebuah logo tersebut dikenang oleh khalayak (Jayanegara dkk., 2017). Pada logo terdapat dua kategori yaitu; 1) berdasarkan kontruksi dengan gambar dan tulisan; 2) logo dengan bentuk-bentuk dasar yang menyatu sehingga membentu suatu objek yang kompleks (Rustan, 2009). Kategori dalam wacana dapat pula dikatakan logo ataupun identitas visual secara umum mengandung beberapa unsur visual yaitu ilustrasi, teks atau 
tipografi, warna, dan bentuk. Unsur-unsur tersebut tentunya melalui pertimbanganpertimbangan dalam merangkai suatu visualisasi yang memiliki nilai estetika. Makna estetika berdasarkan penikmat karya meliputi tingkatan susunan hasil persepsi atau pengamatan yang berhubungan dengan emosi atau perasaan yang diperoleh dari hasil interaksi persepsi memori dan visual (Ari and Setiawan, 2019). Prihal perangcangan pada media komunikasi visual Untuk mewujudkan media yang efektif dan komunikatif, maka dalam proses pengerjaan desain media komunikasi visual..., dalam proses pemilihan dan pengolahan alternatif desain, ... terjadi timbal balik oleh kedua pihak, dan desainer akan memperoleh bahan sebagai acuan dalam proses perancangan (Setiawan, 2017). Pendapat lainnya terkait makna yaitu hubungan langsung dari makna memiliki keterkaitan dengan unsur-unsur lain yang terkadang kemunculannya tidak disadari (Setiawan dkk., 2015)

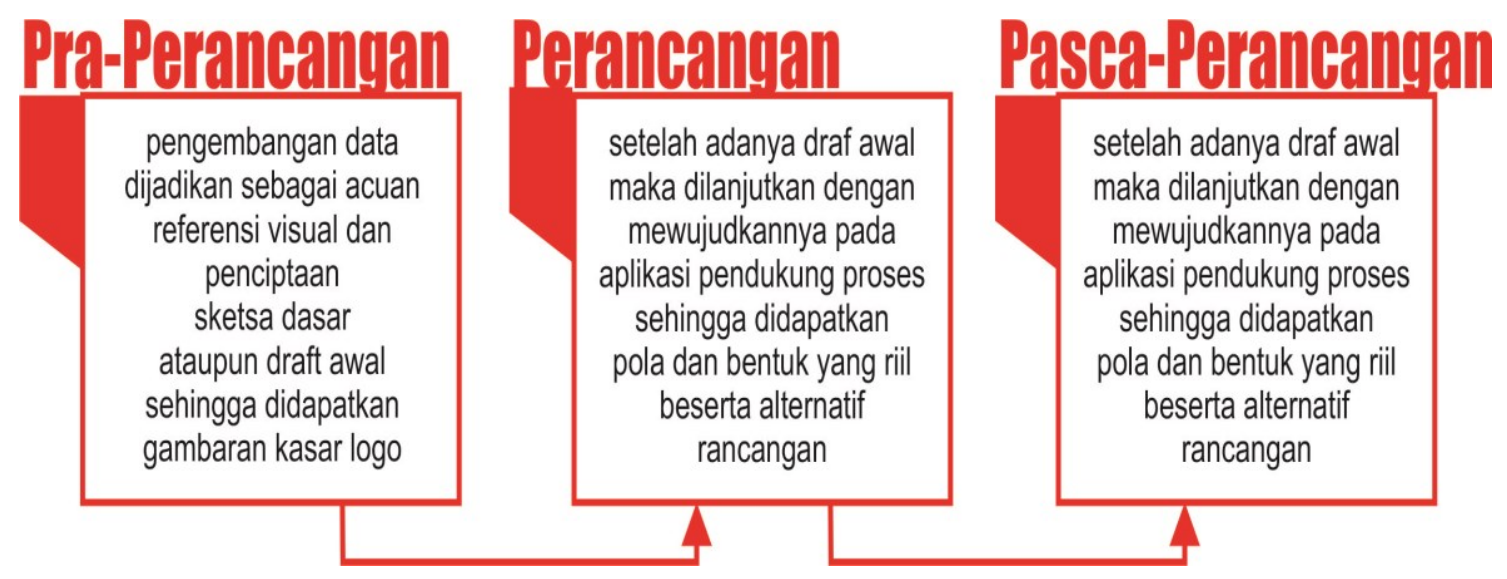

Gambar 6. Bagan perancangan

Pada bahasan mendalam pada penciptaan identitas visual ini dan sebelum beranjak pada implementasi, dirasa perlu pula membuka awalan tentang runut proses yang akan dilakukan. Secara umum perjalanan proses perancangan dalam suatu penciptaan visual, terdapat lima fase yaitu pengembangan, pra-perancangan, perancangan, pasca-perancangan, dan publikasi (Setiawan, 2018). Tiap tahapan atau fase pada proses penciptaan tersebut dapat dijelaskan yakni: (1) pengembangan disebut pula development yaitu proses pengumpulan data, dana, dan RAB serta segala kebutuhan terkait perancangan; (2) pra-perancangan yakni hasil pengembangan data dijadikan sebagai acuan referensi visual dan penciptaan sketsa dasar ataupun draft awal; (3) perancangan yaitu hasil draf awal dijadikan referensi visual untuk menuju pada bentuk riil identitas visual dengan dukungan aplikasi grafis yang relevan; (4) pasca-perancangan yaitu hasil dari fase perancangan lalu difinalisasikan dan siap diimplementasikan pada acuan media; dan (5) publikasi yaitu 
mulai memetakan pilihan implementasi identitas pada beragam media visual dan aturan pemanfaatannya sebagai opsional. Namun pada perancangan logo BMB, hanya menggunakan tiga fase yaitu pra-perancangan, perancangan, dan pascaperancangan, dengan mempertimbangkan percepatan proses penyajian logo sebagai identitas visual yang secara terstruktur dapat dilihat pada gambar 6 .

\section{METODE PERANCANGAN}

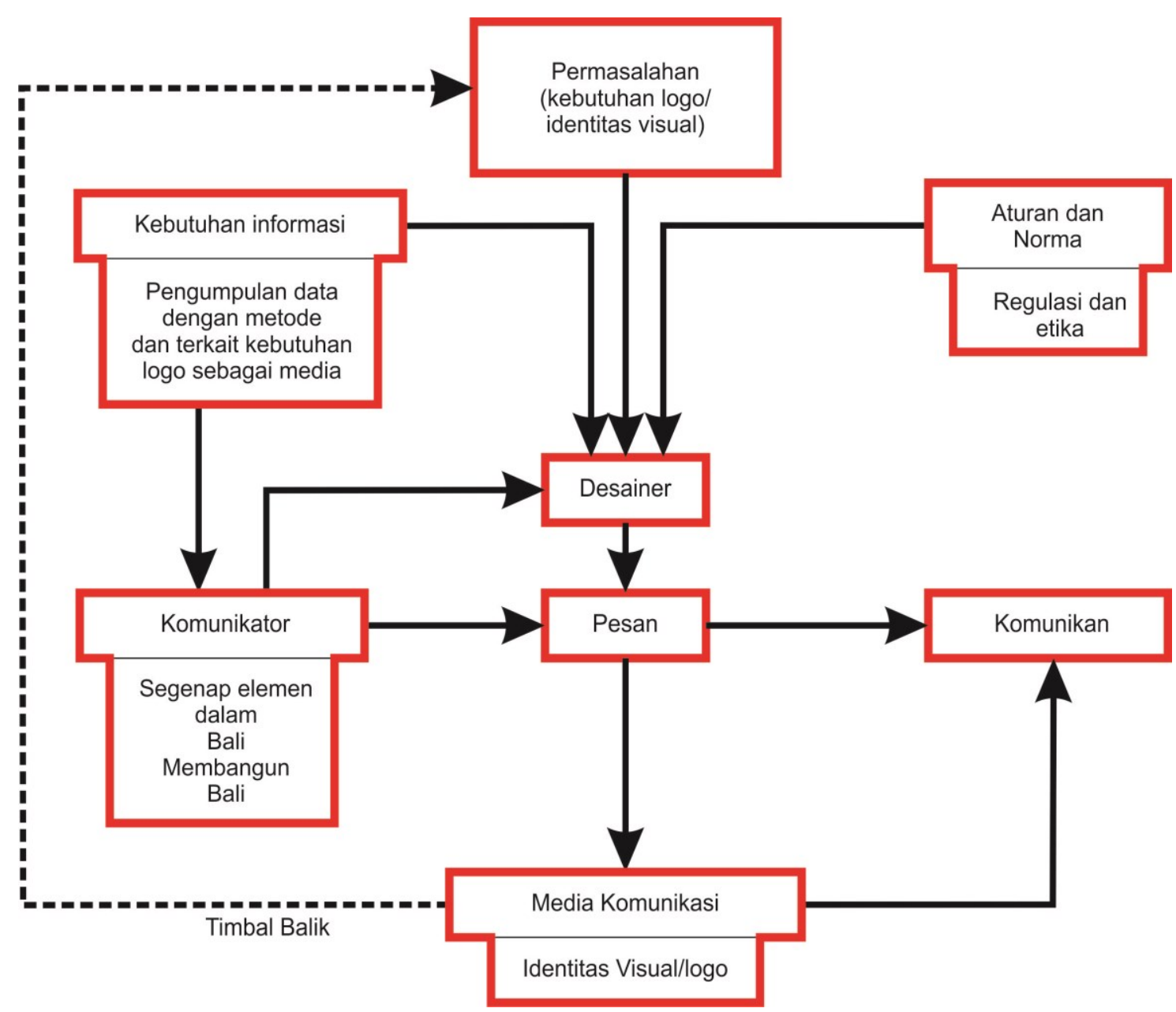

Gambar 7. Bagan pola pikir

Pada perancangan ini merujuk pada perancangan identitas visual untuk Jurnal Bali Membangun Bali dan perancangan ini merupakan dari hasil telaah konsep jurnal dan kebutuhan untuk publikasi online. Perancangan yang dilakukan diawali pula dari analisis referensi atau sunber relevan, yang dilakukan secara alamiah lalu dideskripsikan secara naratif pada artikel ini. Data referendi kemudian diproses menjadi suatu pola pikir dalam perancangan dengan luaran identitas visual Jurnal Bali Membangun Bali yang akan digunakan secara berkelanjutan. Dijelaskan bahwa beragam komponen serta input penting menjadi dasar pengembangan ide menjadi salah satu hal yang perlu dicermati. Pengembangan ide tersebut tanpa meninggalkan 
aturan dan norma yang berlaku, seperti norma hukum, norma sosial, etika dan sebagainya. Input pula didapatkan dari komunikator untuk menghasilkan pesan yang kemudian diwujudkan dalam suatu media komunikasi visual yakni logo Jurnal Bali Membangun Bali. Prihal pola pikir yang telah disebutkan, dapat dilihat pada gambar 7 .

ASUMSI PERANCANGAN

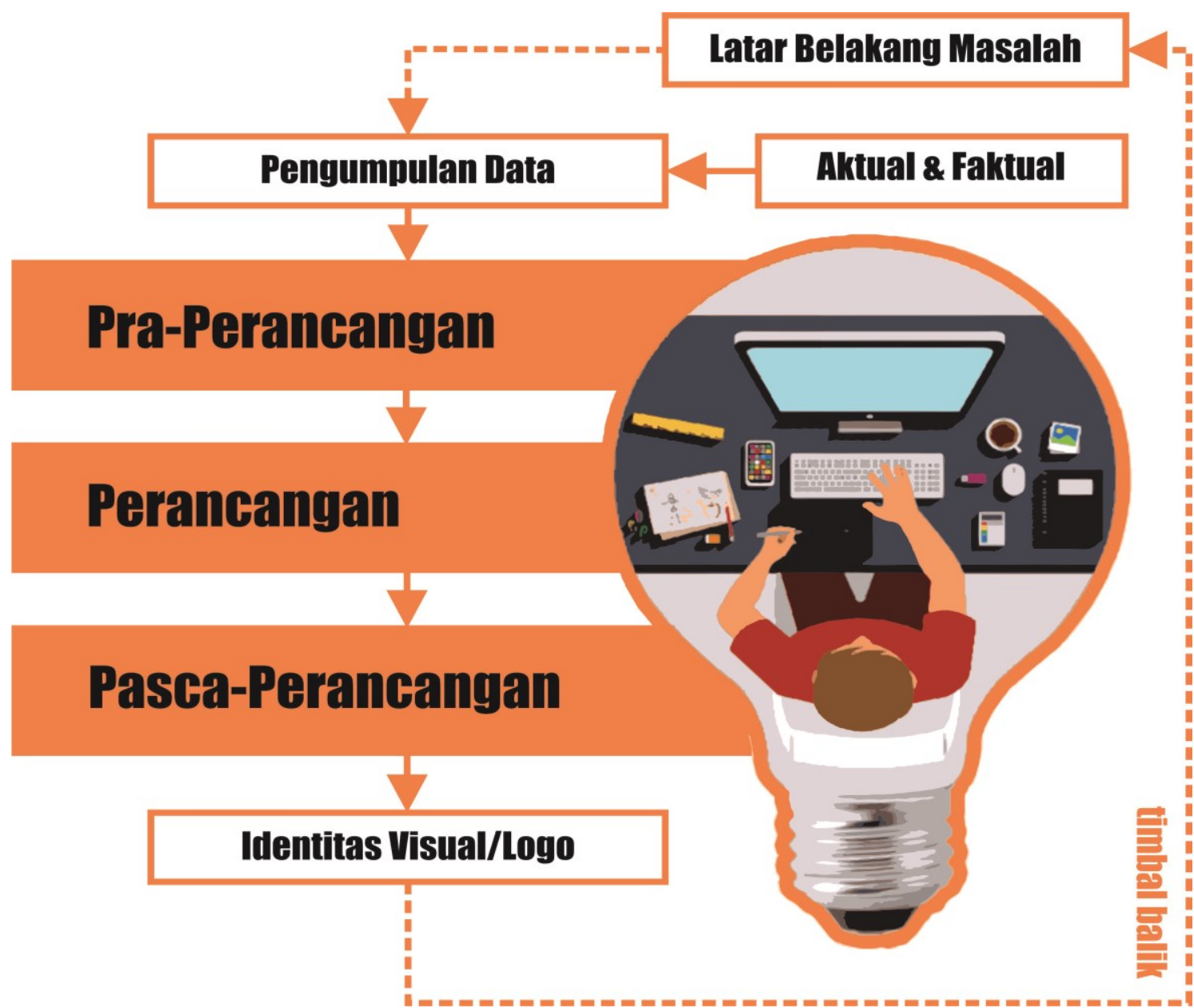

Gambar 8. Pola perancangan

Berdasarkan referensi pola pikir, pemikiran yang dapat diasumsikan pada perancangan adalah sebuah logo yang berkarakter modern. Konsep pembangunan dan Bali menjadi bagian aksen nuansa visual logo dengan mengimbuhkan elemenelemen visual yang berhubungan dengan relasi konseptual. Berdasarkan asumsi, referensi, dan bagan pola pikir pula, secara umum melalui tiga prosedur perancangan yaitu (1) pra-perancangan mengumpulkan referensi visual yang dianggap memiliki hubungan dengan konsep sehingga didapatkan draf kasar perancangan seperti dalam bentuk sketsa awal logo; (2) perancangan dilakukan merealisasikan draf rancangan awal menuju bentuk riil berdasarkan prinsip desain yang berlaku dengan bantuan 
aplikasi grafis yang mendukung; dan (3) pasca-perancangan memfinalisasikan rancangan menuju desain terpilih sekaligus simulasinya pada media publikasi. Pada asumsi perancangan, dapat pula direncanakan strategi tindakan yang berkaitan dengan management design project, perencanaan tata kelola media secara berkelanjutan, dan strategi lainnya. Asumsi yang telah dijelaskan dapat dilihat pada gambar 8.

\section{PEMBAHASAN}

\section{Pra-Perancangan}

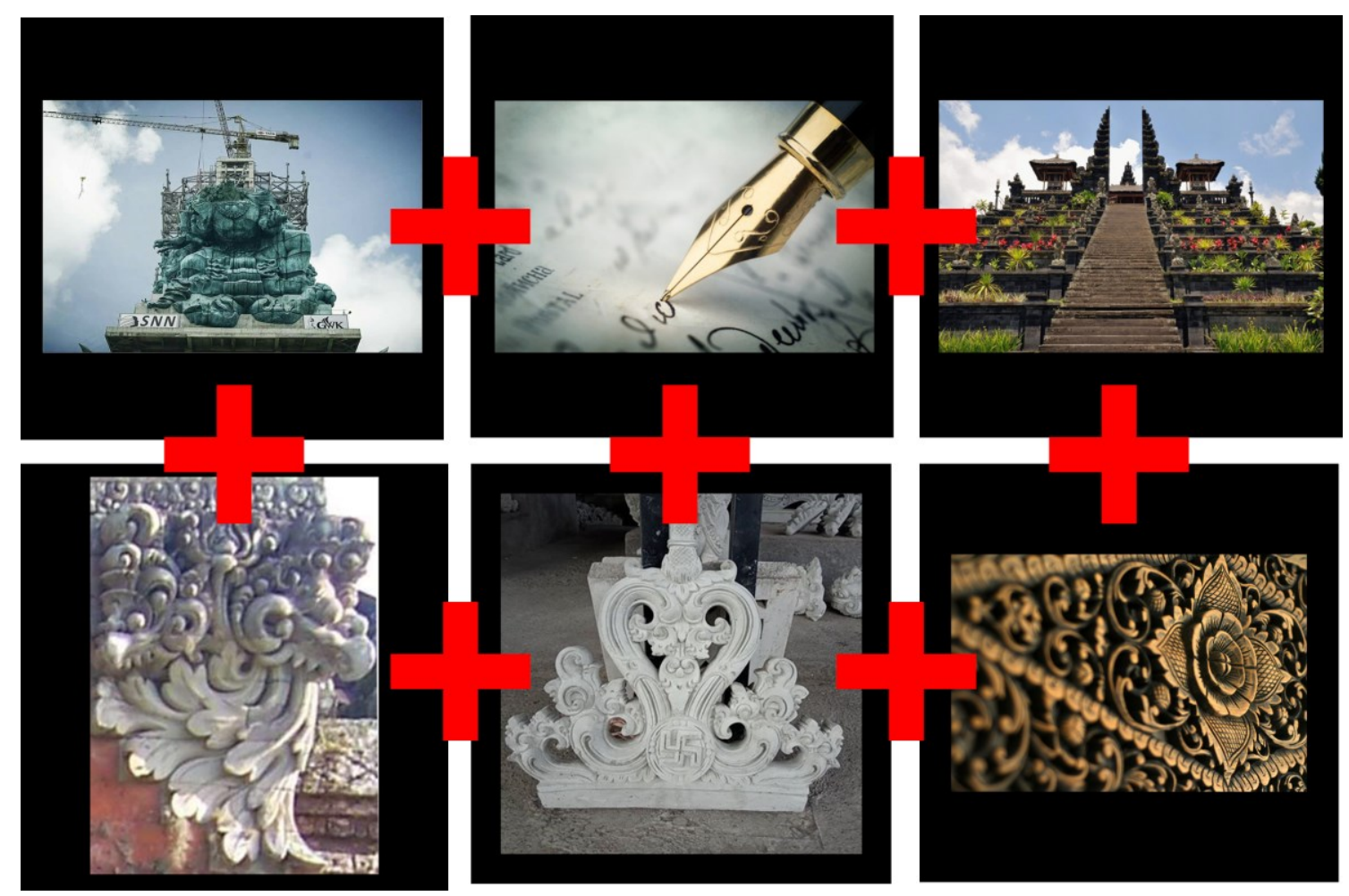

Gambar 9. Eksplorasi ide berdasarkan nuansa

[Sumber: penulis]

Pada asumsi perancangan telah dijelaskan pola perancangan dalam penciptaan identitas visual Jurnal Bali Membangun Bali yang diawali dengan praperancangan. Jika kembali pada referensi konsep, maka pra-perancangan disusun berdasarkan kaitan-kaitan elemen yang dianggap seiring. Beberapa elemen atau komponen yang berpengaruh pada susunan struktur pra-perancangan, yang dapat diambil adalah nuansa pembangunan, nuansa Bali, nuansa budaya, dan nuansa dari $B M B$ sendiri. Mengingat logo adalah perwakilan entitas, maka semua nuansa yang ada akan diformulasikan dengan pertimbangan-pertimbangan dalam asas perancangan. Sehingga hasil dari pra-perancangan ini merupakan draf identitas visual yang siap 
untuk proses lanjutan. Pra-perancangan merupakan bagian pula dalam ekplorasi ide yang lebih konkret.

\section{Perancangan}

Pada fase perancangan, input ide berdasarkan asumsi perancangan dan praperancangan mulai disatukan. Penyatuan pada perancangan dilaksanakan dengan acuan referensi fisual yang dianggap relevan dan penggalian ide-ide yang sejalan dengan konsep. Proses perancangan menggunakan program atau aplikasi grafis dalam pelaksanaannya, proses tranformasi imaji, modifikasi gambar, stilir, pemilihan ilustrasi, tipografi, bentuk, warna, dan beragam proses selalu mempertimbangkan asas-asas dalam desain. Pada proses perancangan mungkin terlihat sederhana namun sudut pandang yang perlu dibangun adalah bukan pada satu titik proses. Perlu diingat bahwa dalam perancangan terdapat runut proses sebelum dan sesudah rancangan tersebut terselesaikan. Hal inilah yang banyak tidak dipahami awam, prihal proses yang tidak terlalu terlihat di permukaan dan oleh sebab itu penilaian terhadap sebuah rancangan khususnya di bidang desain komunikasi visual masih dipandang sebelah mata.

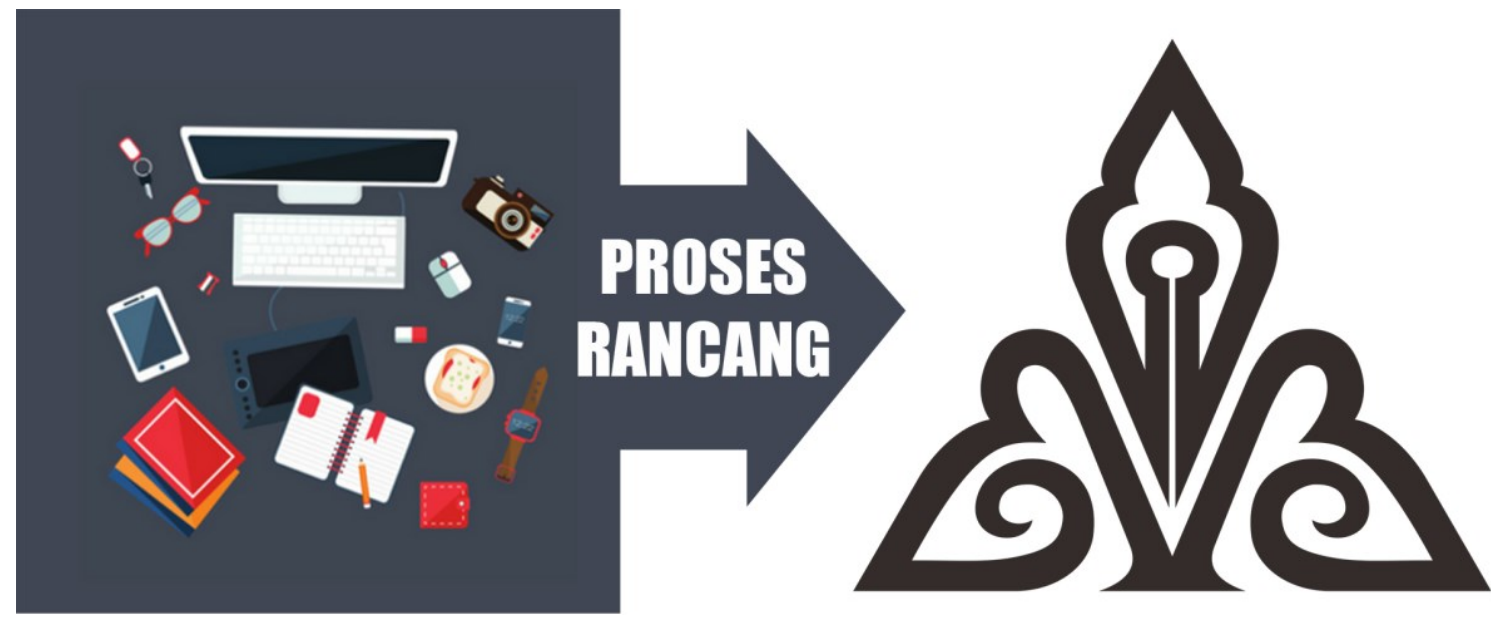

Gambar 10. Penyederhanaan proses perancangan dan hasil rancangan [Sumber: penulis]

Kembali pada rangkaian perancangan, kini hasil sudah terlihat dan siap untuk diujikan pada media. Ekstraksi ide menjadi kenyataan dan berfungsi sebagai media menjadi pertimbangan lain, misal pemilihan elemen warna hanya menggunakan sifat tunggal karena hal ini mempertimbangkan fleksibilitas media. Sehingga jika acuan media berubah ubah maka elemen visual yang terkandung dalam logo tidak menjadi permasalahan terkait prinsip-prinsip desainnya seperti pada permasalahan komosisi 
dan harmoni pada acuan media akan lebih mudah diimplementasikan. Hal ini pula bisa berubah sesuai tujuan tanpa merusak struktur dari logo yang telah final dirancanng melalui proses yang kompleks.

Ciptaan yang telah dirancang memiliki unsur-unsur dari ide sebelumnya diekstraksi dan disusun. Halnya suatu identitas visual yang mewakili entitas, penciptaan logo juga memiliki makna filosofis pada tiap elemen visual yang terkandung dan terstrukturisasi pada logo. Adapun struktur filosofis tersaji pada gambar tabel 2 tentang elemen visual dan maknanya.

Tabel 2. Makna filosofis elemen visual identitas BMB [Sumber: penulis]

\begin{tabular}{ll}
\hline No. & Elemen Visual \\
& \multicolumn{1}{c}{ Makna Filosofis } \\
1. Pena & Pemikiran, tujuan, dan kecerdasan dalam \\
& membangun Bali (menuju fokus); BMB \\
& sebagai wadah menuangkan pikiran, \\
& penyebaran informasi dan pengetahuan.
\end{tabular}

2. Aksen alur ukiran Bali (visual Budaya dan pengetahuan kearifan lokal keseluruhan, cecawian, mas- sebagai landasan pergerakan masan, simbar, pepatran) pembangunan.

3. Bentuk segitiga dan enam sudut Pembangun berlandaskan Tri Hita Karana dan Nangun Sat Kerthi Loka Bali.

4. Huruf BMB (hurub B bolak balik Penyatuan visi dan sinergitas penyatuannya menjadi huruf $\mathrm{M}$, pembangunan Bali. alur ornamen Bali kuping guling)

5. Teks Jurnal Bali Membangun Bali Menerangkan media sebagai wadah publikasi tentang pembangunan Bali. 


\section{Pasca-Perancangan}
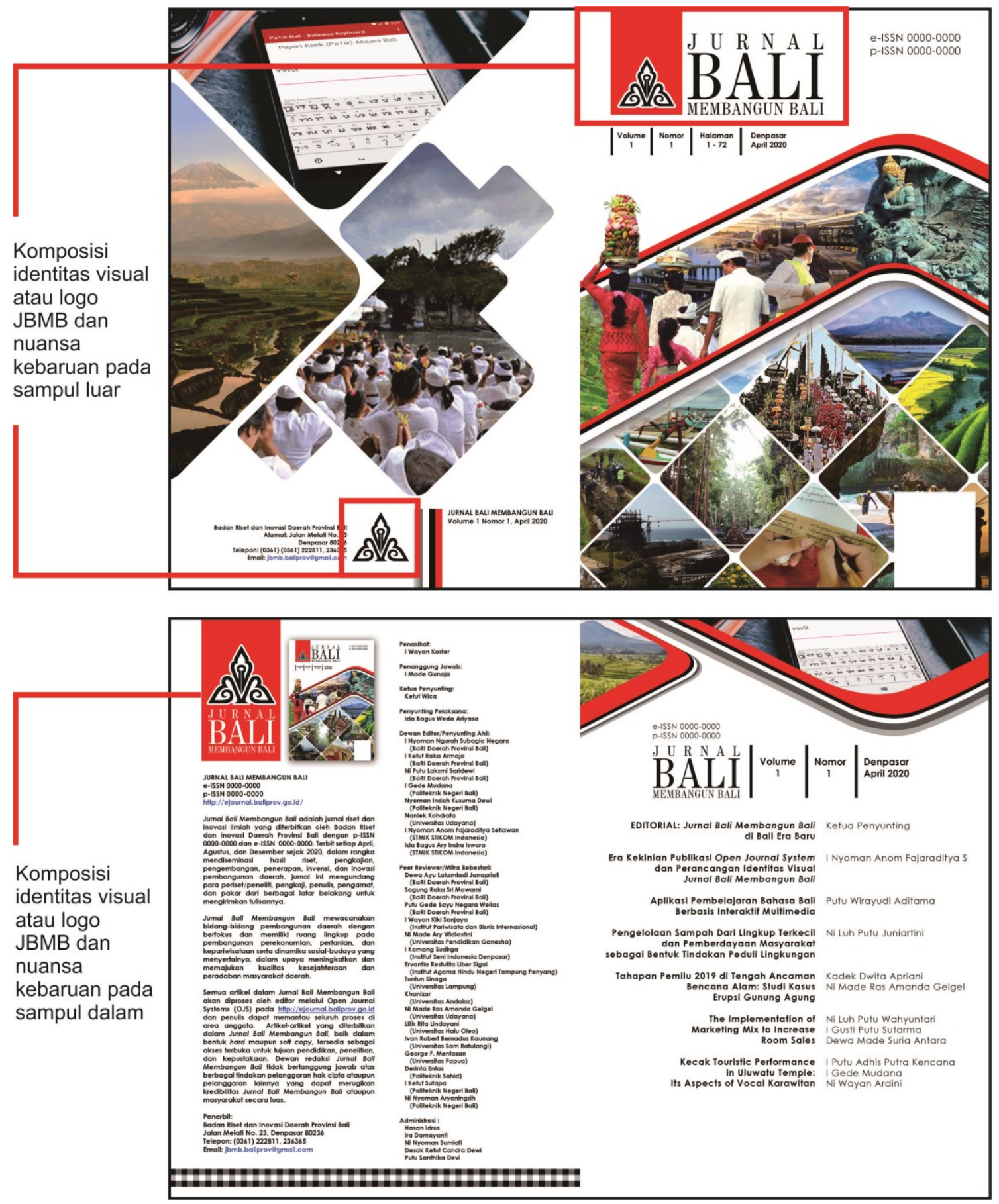

Gambar 11. Simulasi komposisi identitas visual pada sampul publikasi [Sumber: penulis]

Setelah melalui fase perancangan yang ditunjukkan dengan adanya hasil rancangan identitas visual, maka dilanjukkan menuju pasca-perancangan. Pada pasca-perancangan adalah proses simulasi implementasi logo yang telah diciptakan pada acuan media yang saat ini masih pada sampul media publikasi. Hal ini bertujuan agar penempatan saat implentasi pada kenyataan, identitas visual yang telah 
dirancang memiliki proporsi yang baik dan jelas terlihat sehingga identitas visual sebagai pembawa pesan dapat berfungsi dengan baik.

\section{KESIMPULAN}

Berdasarkan paparan yang telah dilakukan pada artikel ini terdapat beberapa simpulan terkait dua agenda pembahasan yaitu: (1) media publikasi sangat penting untuk diadakan karena merupakan sebagai wadah diseminasi tentang kemajuan dan tolok ukur pembangunan khususnya di provinsi Bali; (2) publikasi dalam bentuk ilmiah harus digalakkan, apalagi dampaknya secara luas pada kemajuan suatu negara; (3) media publikasi harus didukung berbagai lapisan, sebagaimana halnya pertanggung jawaban atau kewajiban menyebarluaskan hasil kajian, utamanya tentang pembangunan di Bali; (4) sesuai dengan konsep baru dari Jurnal Bali Membangun Bali, informasi tentang berbagai hal dalam pembangunan daerah dapat di susun dan dipublikasikan agar dapat terpantau oleh khalayak atau bahkan menjadi tolok ukur pembangunan secara berkelanjutan; (5) sebagai pelopor publikasi, Jurnal Bali Membangun Bali (JBMB) menuju pada publikasi secara online atau open access systems, mengingat tuntutan kemajuan dan kebutuhan prihal publikasi dalam era kekinian; (6) kesiapan secara online maka membutuhkan suatu identitas secara visual untuk membawa pesan visi misi yang ada, dan perwakilan entitas tersebut adalah penciptaan sebuah logo JBMB; (7) penciptaan logo tidak sesederhana pemikiran awam, namun melalui proses riset dan runut dalam mengekstraksi gagasan dan ide; dan (8) sebagai wadah pemikiran, BMB dapat pula mengakomodir beragam gagasan dan strategi pembangunan ke depan.

Selanjutnya beberapa saran diantaranya: (1) pemanfaatan identitas visual atau logo tidak hanya untuk ditempatkan pada sampul saja, namun dapat pula digunakan pada program lainnya yang masih berhubungan langsung dengan JBMB; (2) adanya pengembangan secara online maka dibutuhkan pula infrastruktur dan sumber daya profesional yang mengetahui seluk beluk publikasi online dan berhubungan dengan pengembangan arah publikasi; (3) pengembangan dapat pula dilakukan secara swakelola dengan lembaga tertentu namun tetap dalam pengawasan institusi induk publikasi tersebut bernaung; (4) pengembangan publikasi diharapkan tidak hanya satu wadah, namun perlu pula dipertimbangkan membuat wadah lainnya yang lebih mengkhusus; (5) perlu adanya pertimbangan untuk pengembangan dalam program kerja tetap, terkait pemeliharaan dan pengembangan lainnya; dan (6) terkait penggunaan logo, perlu ada tata kelola yang jelas agar pemanfaatan logo tidak disalah gunakan dengan mengadakan suatu aturan yang jelas misal tersusun dalam graphic standart manual. 


\section{DAFTAR PUSTAKA}

Ari, I. A. D. K., dan Fajaraditya Setiawan, I. N. A. 2019. Study of Vulgar Text and Ilustrasi on T-Shirt. Jurnal Bahasa Rupa, 2(2), 80-85. https://doi.org/10.31598/bahasarupa.v2i2.297.

DIKTI, D. 2011. Pedoman Akreditasi Terbitan Berkala Ilmiah. Jakarta: Direktur Jenderal Pendidikan Tinggi Kementerian Pendidikan Nasional Republik Indonesia, diambil dari https://kelembagaan.ristekdikti.go.id/wpcontent/uploads/2016/11/PerDirjen49-Dikti-Kep-2011TerbitanBerkalallmiah.pdf.

DIKTI, K. 2016. SINTA - Indeks Sains dan Teknologi. diambil 27 Desember 2019, dari http://sinta2.ristekdikti.go.id/about.

Guru, M. 2013. Jenis Publikasi Ilmiah. diambil 27 Desember 2019, dari https://mediaguru.co.id/jenis-publikasi-ilmiah/.

Jayanegara, I. N., Setiawan, I. N. A. F., dkk. 2017. Perancangan Identitas Visual Laboratorium E-government and Enterprise System STMIK STIKOM Indonesia. S@ CIES, 7(2), 109-117. diambil dari https://ejournal.stikiindonesia.ac.id/index.php/sacies/article/view/185.

Nurudin, W. 2013. Pengertian OJS. diambil 27 Desember 2019, dari http://raghibnuruddin237.blogspot.com/2013/01/pengertian-open-journalsystem.html.

Putra, I. W. W. I. 2018. Pengantar Kepala Bappeda Litbang Provinsi Ball. Bali Membangun Bali, 1(1), i-ii.

Rustan, S. 2009. Mendesain Logo. Jakarta: Gramedia.

Setiawan, I. N. A. F. 2017. Kajian Rancangan Promo Album Faito 61 Tahun 2008. Jurnal Bahasa Rupa, 1(1), 1-10.

Setiawan, I. N. A. F. 2018. Sinema Paradoks: Pengantar dan Konteks Kontemporer. (I. N. Jayanegara, Ed.). Denpasar: STMIK STIKOM Indonesia.

Setiawan, I. N. A. F., Jayanegara, I. N., dkk. 2015. Perancangan Video Dokumenter Eksistensi dan Motivasi Tato Rangda di Denpasar. S@Cies, 6(1), 41-46. https://doi.org/10.31598/sacies.v6i1.96.

Setiawan, I. N. A. F., dan Jayanegara, I. N. 2019. Sistem Tanda Visual Logo STMIK STIKOM Indonesia. Denpasar: STMIK STIKOM Indonesia. 